\title{
A DECISION SUPPORT SYSTEM FOR RISK MANAGEMENT WITH APPLICATION TO WATER SUPPLY SYSTEMS IN EGYPT
}

\author{
Mohamed Ahmed Reda \\ Assistant Professor, Civil Engineering Dept., Canadian International Colleague (CIC), \\ El Sheikh Zayed, Giza, Egypt.

\section{Amir Mohamed Mobasher} \\ Associate Professor, Civil Engineering Dept., Fac. of Eng., \\ Al-Azhar Univ., Cairo -777, Egypt
}

\begin{abstract}
Water supply systems (WSS) are commonly collected of water sources (WS), transmission pipes, treatment plants, and distribution networks from source to tap and generally are subjected to variation of risks. However, the present study provides an adaptive risk management framework for water supply systems that provides drinkable water to various Cairo regions. However, three risk assessment and management case studies were conducted at different Cairo drinkable water supply systems during 20152018, including the location served by North Helwan, Fostat and ElMarg water treatment plants (WTP). The work scope was involved in two main parts. In the first part, the common risk challenges in water distribution systems (WDS) are assessed to adopt the methodology for risk management in the Cairo water system. Moreover, these types of risks are sectored according to their potential impact and probability of occurrence is developed. While, the second part involved on developing a Grey Relational Analysis (GRA) approach to integrate risk alternatives mitigation based on supply reliability, environmental, social and economic key criteria and consequently supply decision support on the choosing of risk response strategies according to the correlation between their reference and comparability sequences. Then, in order to monitor the tolerability of acceptable residual risk levels after applying the proposed alternative strategies, the principal of As Low As Reasonably Practicable (ALARP) is applied. The outcomes of this paper displayed that several risks constitute the main parameter within which to characterize water supply systems and its operation, thus, it is a key factor in supply and distribution system operation and planning decision making. Moreover, this study put forward the basis for water services providers to mitigate the risk of non-compliance and realize the target supply standards within the short, medium and long term.
\end{abstract}


A Decision Support System for Risk Management with Application to Water Supply Systems in Egypt

Keywords: Water Supply Systems, Risk Management, WTP, GRA, ALARP

Cite this Article: Mohamed Ahmed Reda and Amir Mohamed Mobasher, A Decision Support System for Risk Management with Application to Water Supply Systems in Egypt, International Journal of Civil Engineering and Technology, 11(11), 2020, pp. 01-16. https://iaeme.com/Home/issue/IJCIET?Volume=11\&Issue=11

\section{INTRODUCTION}

The primary supply of drinkable water in Egypt is the Nile River, which receives wastewater and drainage from various actions (El-Sadek, 2007). World heads progressively realize that safe drinkable water is an important part of sustainable development. The health risks of people associated with the presence of pathogens depend on water use and pathogen concentration in water (Garcia-Armisen et al., 2007). Fecal pointer bacteria can estimate the quantity of feces and secondarily estimate the attendance and quantity of fecal pathogens in the water (Reynolds et al., 2008). Drinkable water should encounter particular standards and guidelines to achieve good public health and be free of pathogenic bacteria. The Drinkable water cleansing plants are specially designed to eliminate chemical and microbial contamination of raw water through the treatment stage, especially in the disinfection stage, where chlorine is added to kill bacteria and pathogens that cause water-borne diseases. The attendance of bacteria in drinkable water dangerously influences public health, which is an emerging problem in the drinkable water manufacturing (Bitton, 1994). There are many reasons for this situation. The main reason may be the lack of a generally accepted calculation method. This is due to some special problems in the distribution network, because it is difficult for them to rely on their actual operation to obtain a reliable information system and have a solid knowledge base which can be used to determine the probability of emergencies representing threats, and these emergencies are the cause of service interruption.

Fortunately, among other advantages, the zoning of distribution networks implemented on many distribution systems makes it possible to assess service risks more reliably and reduce risks more effectively. This can be achieved through departmental configuration and design, or it can be achieved by effectively monitoring the working methods of distribution and formulating effective operating procedures to handle events. Therefore, departmentalization opens the door to separate risk assessment for each department or each property in the separate distribution system.

Insufficiency to present sufficient safeguard and successful treatment will subject societies to the risk of outbreaks of intestinal and other infectious diseases. The microbiological parameters of drinkable water are very important and should not surpassed the limit determined in the water quality guidelines because they indicate the potential danger of water-borne diseases. LeChevallier (2003) and Rifaat (2007) displayed that water polluted with microbial components can cause many diseases. It is expected that 10,000 people die per day from diseases related to water and sanitation, and thousands of people suffer fromassociated illnesses (Bosch et al., 2000). In this regard, enteric pathogens are normally dependable for waterborne sickness (Karaboze et al., 2003).

Egypt's drinkable water sector faces many challenges and may subsequently affect the water supply process: -

- More than $30 \%$ of the total water distribution network lengths are over the age of 30 years.

- $\quad$ The percentage of water loss may exceed $25 \%$ of the total water produced. 
- A relatively low water pressure in some districts zones compared with the required pressure.

- The buried water valves that unable to isolate the zones easily.

- Many WTPs undergone generally from elevated turbidness and reduction in remaining chlorine

- -The overall shortage of filtration and disinfection stages has led to inadequate operation of many sewage treatment plants.

This study aimed to gain insights into three different Cairo geographic locations served by three main WTPs: North Helwan, Fostat and ElMarg. However, in order to achieve the target level of water supply system operation, a methodology is also proposed to assess the challenging risks, while allowing people to focus on the tangible business value of good management of strategic risks.

\section{MATERIAL AND METHOD}

\subsection{Study area}

The Cairo Water Company (CWC) produces more than 6 million cubic meters per day through 11 sewage treatment plants (Kafr Elw, Tibeen, North Helwan, Fostat, El Roda, Rod El Farg, Amerea, Maadi, Mostrod, El Marg and Shubra el Khiema) Of drinkable water to meet the water needs of Cairo Governorate. These WTPs mainly rely on the Nile River and its channels to obtain the raw water needed. This research area involves water supply systems in different locations in Cairo, Egypt. These locations are served by three major WTPs: North Helwan and Fostat and ElMarg WTPs. Figure 1 shows the geographic locations of the study area WTPs.

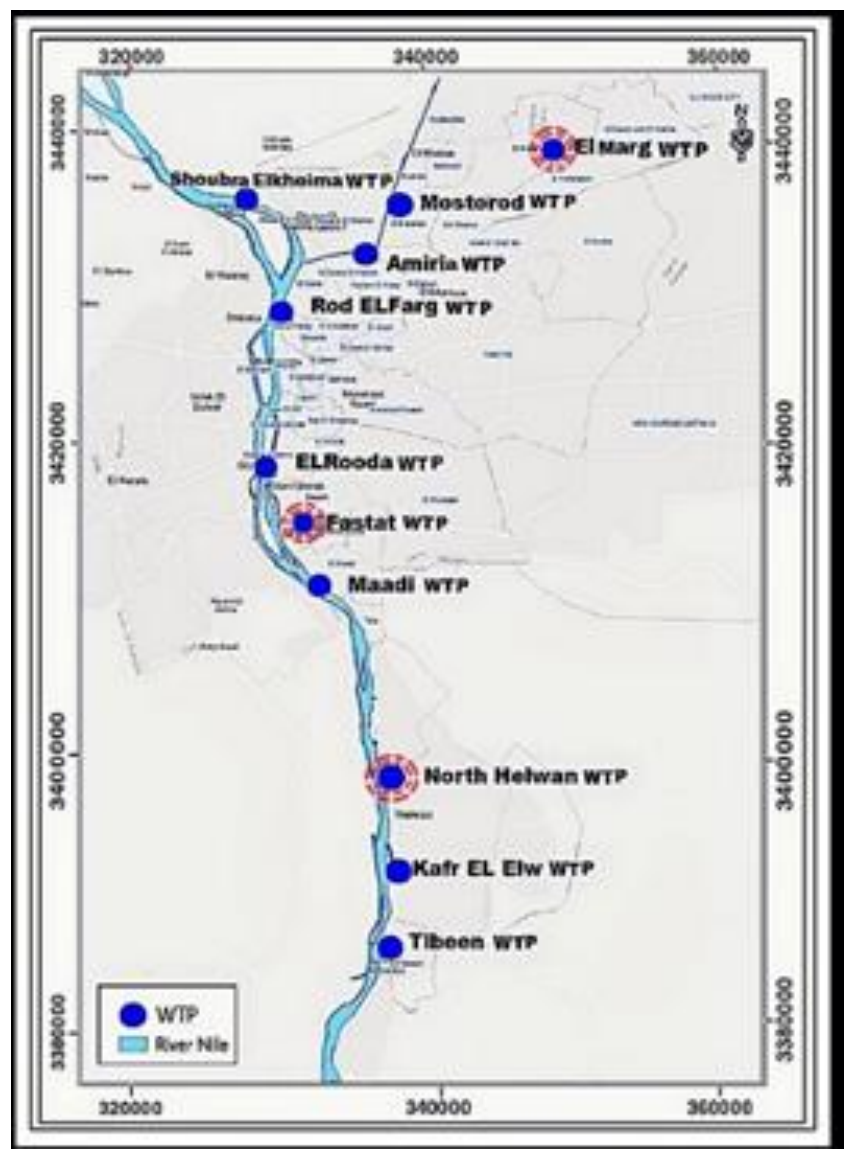

Figure 1 Study Area (CWC, 2014) 
A Decision Support System for Risk Management with Application to Water Supply Systems in Egypt

Table 1 Study Area WTP Basic Information (CWC, 2014)

\begin{tabular}{|l|l|l|l|l|l|}
\hline WTP & $\begin{array}{c}\text { Surface water } \\
\text { source }\end{array}$ & $\begin{array}{c}\text { Annual } \\
\text { average } \\
\text { Raw water } \\
\left(\mathbf{m}^{\mathbf{3}} / \mathbf{d a y}\right)\end{array}$ & $\begin{array}{c}\text { Annual average } \\
\text { Treated water } \\
\text { production } \\
\left(\mathbf{m}^{\mathbf{3}} / \mathbf{d a y}\right)\end{array}$ & $\begin{array}{c}\text { Average } \\
\text { Chorine gas } \\
\text { disinfection } \\
\text { Dose }\left(\mathbf{g} / \mathbf{m}^{\mathbf{3}}\right)\end{array}$ & $\begin{array}{c}\text { Average } \\
\text { Aluminum } \\
\text { Sulphate } \\
\text { Dose }\left(\mathbf{g} / \mathbf{m}^{\mathbf{3}}\right)\end{array}$ \\
\hline $\begin{array}{l}\text { North } \\
\text { Helwan }\end{array}$ & River Nile & 321000 & 283550 & 5.2 & 37 \\
\hline Fostat & River Nile & 1114400 & 1046980 & 5.4 & 52 \\
\hline ElMarg & Ismailia canal & 650000 & 526240 & 5.8 & 59 \\
\hline
\end{tabular}

\subsubsection{Water Supply System (WSS)}

The three previously mentioned WSS elements and their relative sub elements are as follows:-

1. Water intake for draw surface raw water source

2. Water treatment plant

3. Main water transmission pipes and distribution network (WD) including various subcomponents such as tanks and pumps, valves.

Table 1 illustrates the main basic data of the water treatment plants WTPs. in the study area; and Figure 2 illustrates the eight main traditional processes currently used in the water supply system of the study area.

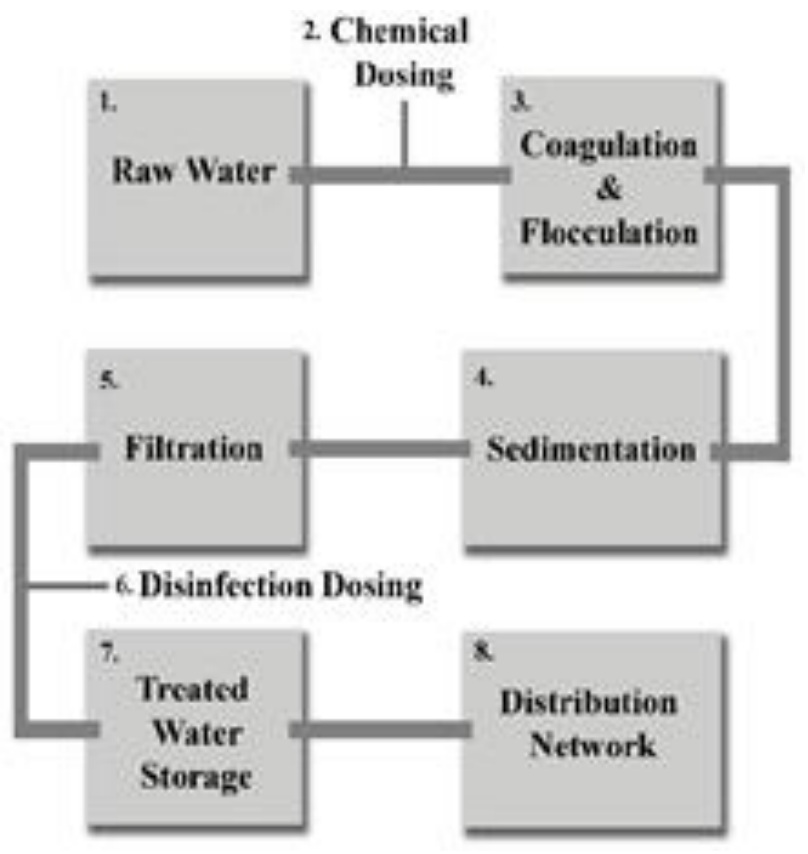

Figure 2 water supply system main processes (CWC, 2014)

\subsection{Method}

Figure 3 illustrates the main parts and steps of the research methodology. However, the first part of the research includes risk identification, assessment and analysis. Then, the second part deals with treatment response and appropriate risk management strategies. In addition, GRA is used to rank risk response strategies. The ALARP framework is used to monitor the effectiveness of the proposed alternative strategies in reducing the risks of the water supply system. 


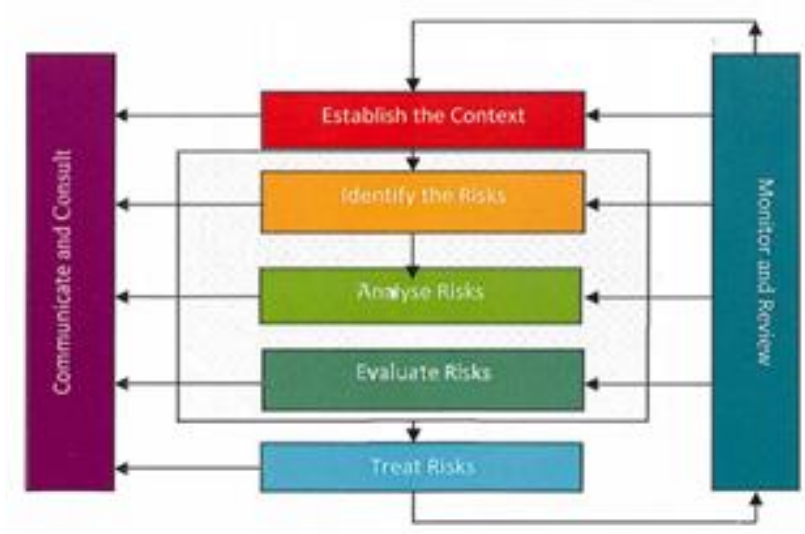

Figure 3 Study Methodology

\subsubsection{Risk Identification and Categorization}

In this research, risk identification is done by brainstorming, interviewing individuals and expert groups. Ask the mentioned professionals to list all potential project risks that may occur (McInnis, 2001). A hierarchical risk breakdown structure (RBS) was developed to promote the concentration of risks, which may lead to problems that affect the efficiency of water supply.

\subsubsection{Risk Analysis}

After risks identification, a total of 16 expert responses were used in the risks arising from implementation of various water supply processes. Therefore, the three corresponding risk categories: high (HR), medium (MR) and low (LR) are determined. Table (2) illustrates the impact, probability scale, risk scores and categories (PMBOK, 2013).

Table 2 Impact, probability scales, indicated risk scores and categories

\begin{tabular}{|c|c|c|c|c|c|}
\hline Probability & \multicolumn{5}{|c|}{ Threats } \\
\hline Very High / 0.9 & 0.05 & 0.09 & 0.18 & 0.36 & 072 \\
\hline High / 0.7 & 0.04 & 0.07 & 0.14 & 028 & 0.56 \\
\hline Moderate / 0.5 & 0.03 & 0.05 & 0.10 & 0.20 & 0.40 \\
\hline Low $/ 0.3$ & 0.02 & 0.03 & 0.06 & 0.12 & 0.24 \\
\hline Very Low / 0.1 & 0.01 & 0.01 & 0.02 & 0.04 & 0.08 \\
\hline Impact & Very Low / 0.05 & Low / 0.1 & Moderate / 0.2 & High / 0.4 & Very High / 0.8 \\
\hline High risk & \multicolumn{2}{|c|}{ Score $>0.14$} & & & \\
\hline Moderate risk & \multicolumn{2}{|c|}{$0.05<$ Score $<0.14$} & & & \\
\hline Low risk & \multicolumn{2}{|c|}{ Score $<0.05$} & & & \\
\hline
\end{tabular}

\subsubsection{Grey Relational Analysis (GRA)}

Grey relational analysis (GRA) is a segment of grey system theory. This method obtains the correlation between the reference sequence and the comparable sequence, and then ranks according to the correlation. The steps of the GRA can be summarized as follows:

Step 1: Obtaining data set and forming the decision matrix:

$$
X_{i}=\left[\begin{array}{cccc}
x_{1}(1) & x_{1}(2) & \ldots & x_{1}(n) \\
x_{2}(1) & x_{2}(2) & \ldots & x_{2}(n) \\
\vdots & \vdots & \ddots & \vdots \\
x_{m}(1) & x_{m}(2) & \cdots & x_{m}(n)
\end{array}\right] \quad i=1,2, \ldots, m \quad j=1,2, \ldots, n
$$


A Decision Support System for Risk Management with Application to Water Supply Systems in Egypt

Here $x_{i}$ indicates the alternatives and $x_{i}(j) i$ is the value of $i^{\text {th }}$ alternative with respect to $j^{\text {th }}$ criterion.

Step 2: Normalization of the decision matrix:

Different normalization formulas are used for the type of the criteria. For benefit (maximization) criteria normalization formula is given in Eq. (2):

$$
x_{i}^{*}=\frac{x_{i}(j)-\min _{j} x_{i}(j)}{\max _{j} x_{i}(j)-\min _{j} x_{i}(j)}
$$

Normalization formula for cost (minimization) criteria is like in Eq. (3):

$$
x_{i}^{*}=\frac{\max _{j} x_{i}(j)-x_{i}(j)}{\max _{j} x_{i}(j)-\min _{j} x_{i}(j)}
$$

For nominal-is-best, if the target value is $\mathrm{x}_{\mathrm{ob}}(j)$ and $\max _{j} x_{i}(j) \geq x_{0 b}(j) \geq \min _{j} x_{i}(j)^{\text {talization }}$ formula is given in Eq. (4):

$$
x_{i}^{*}=\frac{\left|x_{i}(j)-x_{0 b}(j)\right|}{\max _{j} x_{i}(j)-x_{0 b}(j)}
$$

Later, normalized decision matrix is formed as seen in Eq. (5):

$$
X_{i}^{*}=\left[\begin{array}{cccc}
x_{1}^{*}(1) & x_{1}^{*}(2) & \ldots & x_{1}^{*}(n) \\
x_{2}^{*}(1) & x_{2}^{*}(2) & \ldots & x_{2}^{*}(n) \\
\vdots & \vdots & \ddots & \vdots \\
x_{m}^{*}(1) & x_{m}^{*}(2) & \ldots & x_{m}^{*}(n)
\end{array}\right]
$$

Step 3: Generation of the reference series:

The reference value of the $j^{\text {th }}$ criterion $\mathrm{x}_{\mathrm{o}} *(j)$ is determined by taking the maximum normalized value of each criterion with the help of Eq. (6):

$$
\begin{gathered}
x_{0}^{*}(j)=\max _{i=1}^{m}\left\{x_{i}(j)\right\} \\
x_{0}^{*}(j)=\left\{x_{0}^{*}(1), x_{0}^{*}(2), \ldots, x_{0}^{*}(n)\right\}
\end{gathered}
$$

Step 4: Forming the difference matrix:

$\Delta_{\mathrm{oi}}(j)$ distance is calculated. It indicates the absolute value of difference between normalized values $\left(\mathrm{x}_{\mathrm{o}}{ }^{*}\right)$ and reference values $\left(\mathrm{x}_{\mathrm{o}}{ }^{*}\right)$ at the $j^{\text {th }}$ point.

$$
\Delta_{0 i}(j)=\left|x_{0}^{*}(j)-x_{i}^{*}(j)\right|
$$




$$
\Delta_{0 i}(j)=\left|x_{0}^{*}(j)-x_{i}^{*}(j)\right|=\left[\begin{array}{cccc}
\Delta_{01}(1) & \Delta_{01}(2) & \ldots & \Delta_{01}(n) \\
\Delta_{02}(1) & \Delta_{02}(2) & \ldots & \Delta_{02}(n) \\
\vdots & \vdots & \ddots & \vdots \\
\Delta_{0 m}(1) & \Delta_{0 m}(2) & \cdots & \Delta_{0 m}(n)
\end{array}\right]
$$

Step 5: Calculating grey relational coefficient:

$$
\gamma_{0 i}(j)=\frac{\Delta_{\min }+\zeta \Delta_{\max }}{\Delta_{0 i}(j)+\zeta \Delta_{\max }}
$$

Here,

$$
\Delta_{\max }=\max _{i} \max _{j} \Delta_{0 j}(j), \Delta_{\min }=\min _{i} \min _{j} \Delta_{0 i}(j) \text { and } \zeta \in[0,1] . \zeta \quad \text { is distinguishing }
$$

coefficient and usually taken as 0.5 by the decision makers in the literature as this value offers good stability and distinguishing effects (Özçelik \& Öztürk, 2014).

Step 6: Calculating the degree of grey coefficient

If the criteria weights equal to each other Eq. (11) is used:

$$
\Gamma_{0 i}=\frac{1}{n} \sum_{j=1}^{n} \gamma_{0 i}(j)
$$

If the criteria have different weights, grey coefficient $\Gamma_{0 i}$ an be calculated via Eq. (12).

$$
\begin{gathered}
\Gamma_{0 i}=\sum_{j=1}^{n}\left[w(j) \cdot \gamma_{0 i}(j)\right] \\
\sum_{j=1}^{n} w(j)=1
\end{gathered}
$$

Here $\mathrm{w}(j)$ indicates the weight of the $j^{\text {th }}$ criterion.

$\Gamma_{0 i}$ grey relational grade shows the similarity of alternative and reference series (Özçelik \& Öztürk, 2014).

Step 7: Determining the overall performance of alternatives

Overall performances of alternatives under all criteria are determined according to the grey relational grade. The alternative with the highest grade of relation will be associated as the best alternative.

\subsubsection{Principal of (ALARP)}

The ALARP principal is based on the functional thinking of acceptable or tolerable risks. However, it helps to define the boundaries that can be used to determine acceptable and unacceptable risks (Rosén et al., 2007). However, it helps to define the boundaries that can be used to determine acceptable and unacceptable risks (Rosén et al., 2007). Figure 4 illustrates the principle of the ALARP diagram, which includes an upper limit and a lower limit to divide unacceptable and acceptable risks. 


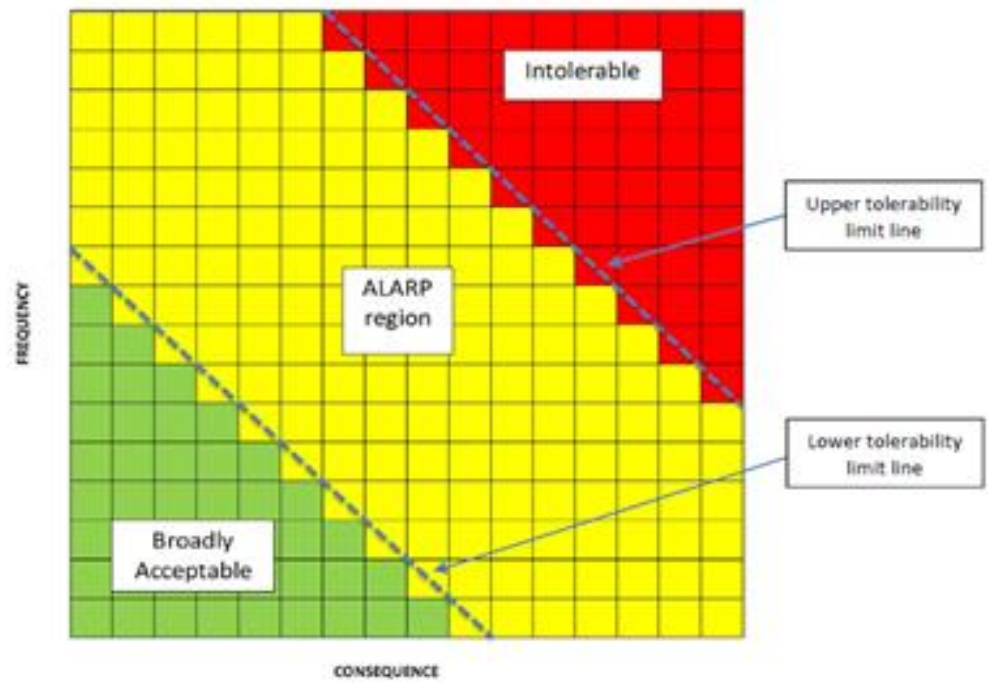

Figure 4 ALARP Diagram

The ALARP concept is mainly illustrated by Figure 4, with high risk at the top (in red), low risk at the bottom (green) and medium risk is situated somewhere in the middle. When a risk is decreased by the study developed strategies, the degree of risk can be decreased from high to low. The risk of exceeding the allowable upper limit cannot be tolerated, and the risk must be decreased. Among the Upper and the Lower Tolerability Limit, the risk is only tolerable if it is ALARP, which denotes that all sensibly workable risk reduction measures have to be detected and applied. Finally, under the Lower Tolerability Limit, risk is generally tolerable or acceptable. ALARP is a point at which a risk is decreased so low that additional risk reduction measure is not needed.

A risk reduction alternative may decreases the eventuality and/or the importance of an event. The variation in risk level an alternative $(j)$ is used to estimate effect $(E j)$ of that alternative. Therefore, $E j$ is estimated utilizing Equation (14) where $R O$ is the existing risk level of a certain unsought event and $R j$ is the anticipated new risk level after alternative $j$ has been applied.

$$
E j=[(R 0-R j) / R 0]^{*} 100
$$

The effect ( $E j)$ hence extracts, in percentage, what amount of the initial risk level is anticipated to be reduced.

\section{RESULTS AND DISCUSSION}

\subsection{RBS Results}

Figure 5 shows the developed hierarchical RBS that based on risk categories. Moreover these risks are breached down beginning with higher-level categories and ongoing down into sublevels of risk. 


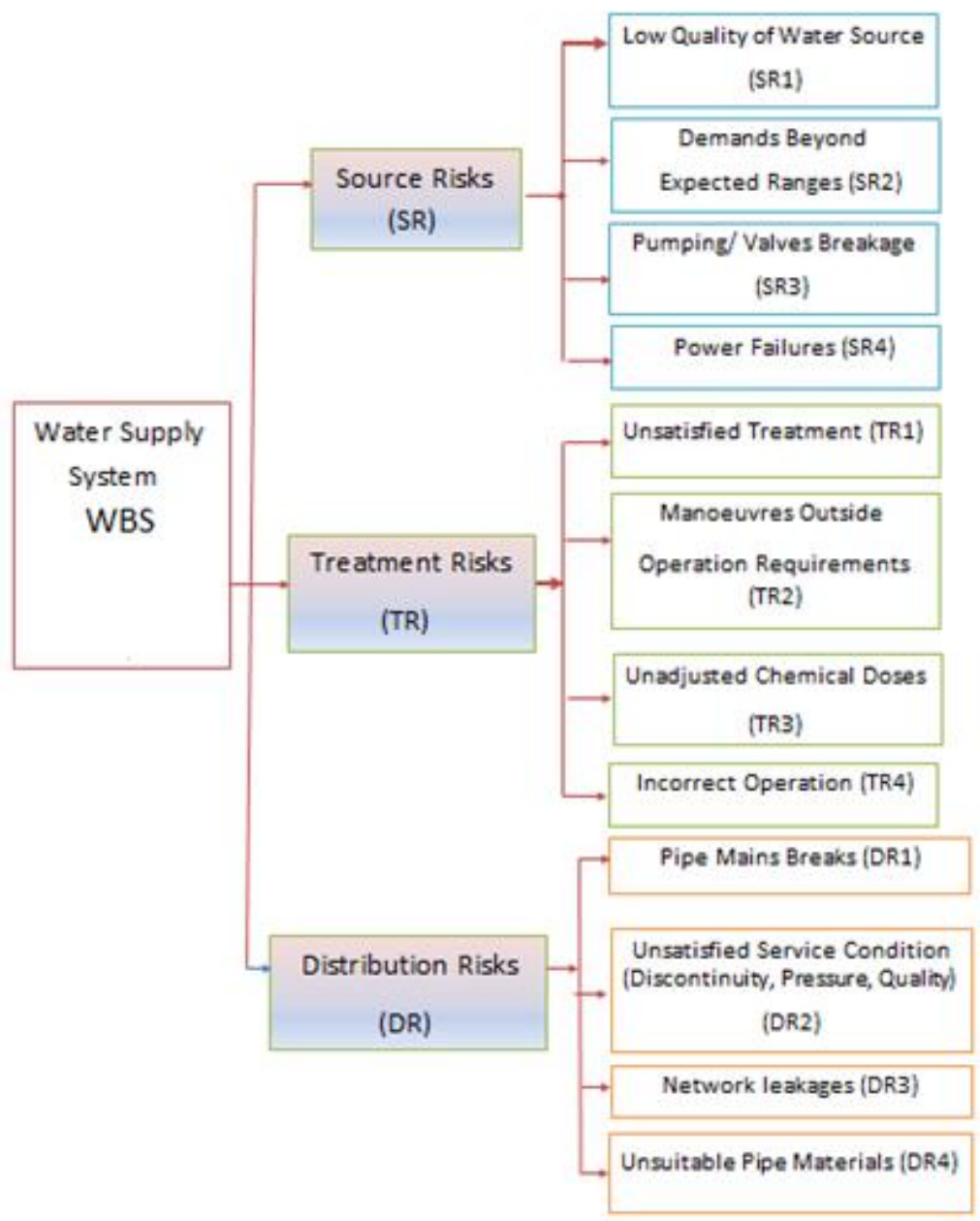

Figure 5 Water Supply System RBS

The developed RBS can provide a support in the later stages (risk analysis and risk response), since it offers an overview on the risks which affect the water supply systems. Table 3 illustrates the developed generic risk matrix , which is mainly used for quantitative risk analysis in this research. However, the key benefit of the devolved matrix is it's important for treatment responses and the required risk management strategies too.

Table 3 Generic Risk Matrix

\begin{tabular}{|c|c|c|c|c|}
\hline Risk & Risk Probability & Risk Impact & Risk Score & Risk Category \\
\hline SR1 & 0.70 & 0.40 & 0.28 & HR \\
\hline SR2 & 0.30 & 0.40 & 0.12 & MR \\
\hline SR3 & 0.50 & 0.40 & 0.20 & HR \\
\hline SR4 & 0.70 & 0.1 & 0.07 & MR \\
\hline TR1 & 0.50 & 0.80 & 0.40 & HR \\
\hline TR2 & 0.90 & 0.40 & 0.36 & HR \\
\hline TR3 & 0.90 & 0.40 & 0.36 & HR \\
\hline TR4 & 0.90 & 0.40 & 0.36 & HR \\
\hline DR1 & 0.70 & 0.40 & 0.28 & HR \\
\hline DR2 & 0.90 & 0.40 & 0.36 & HR \\
\hline DR3 & 0.90 & 0.20 & 0.18 & HR \\
\hline DR4 & 0.30 & 0.10 & 0.03 & LR \\
\hline
\end{tabular}


A Decision Support System for Risk Management with Application to Water Supply Systems in Egypt

From Table (3), it can be noted from the developed matrix that most of risks in the three main water supply stages: water source, treatment and distribution are classified into high-risk category. However, these risks will require active management measures to treat and mitigate their effects.

\subsection{Risk Response Alternatives}

The results of the Developed GRM will be used as a benchmark for formulating the required response. However, in order to reduce the risk of the water supply system, the following alternative solutions and strategies have been proposed:-

\section{I- Water Source Risks Response Alternatives (SA)}

A. Online measurement of raw water quality (SA1): by fitting automatic turbidity meter with remote data transfer.

B. Applying automatic system for monitoring water suction levels (SA2): to determine its urgent level beyond which water quality may be affected.

C. Sludge treatment (SA3): Most of Cairo WTPs discharge the sludge into the Nile without any treatment. The sludge consists of impurities removed and precipitated from the raw water and the residues of any treatment chemicals used, which can cause the quality of the water source to deteriorate. However, this proposed alternative focuses on stopping the sludge disposal effluent from WTPs the water source and applying sludge treatment alternative.

D. Installation of water meters to regulate the demand (SA4)

E. Alternative water sources (SA5): such as constructing new deep well system as an alternative source for ground water to be a stand by or auxiliary for the existing surface water source.

\section{II- Treatment Plants Risks Response Alternatives (TA)}

A. Flow changes regimes (TA1): to satisfy standard WTPs operation procedures in various flow changes cases after transient conditions.

B. Resilience capacity (TA2): to cope with different types of abnormal circumstances.

C. Dosing regimens (TA3): to insure proper chlorination disinfection and aluminum sulphate coagulation doses.

D. Emergency operating procedures (TA4): to reduce the disturbance impact effect caused due to emergency cases.

\section{III- Water Distribution Risks Response Alternatives (DA)}

A. Leakage reduction (DA1): by fixing pipe leakages and upgrading the network.

B. Installation of fixed water flow and pressure monitoring meters (DA2): at various water distribution network locations to control demand

C. Introducing network reliability analysis (DA3): for identifying pipelines at risk

D. Limiting number of low water pressure / flow situations (DA4)

E. Replacing valves with new automatic control types (DA5) 


\subsection{Risk Management Strategies Evaluation}

\subsubsection{Evaluating Criteria}

The comparative evaluation of suggested alternatives was founded on criteria and indicators that are of essential significance for WSS as determined by the categories detected, containing supply reliability, environmental, Social and economic key criteria. Table 4 condenses the indicators that are utilized to evaluate the influences and impacts of alternatives.

Table 4 Criteria utilized for the alternatives evaluation

\begin{tabular}{|c|c|c|}
\hline Criteria & Sub- Criteria & Symbol \\
\hline \multirow{3}{*}{ Supply Reliability } & Future Demand Capacity & SRC1 \\
\cline { 2 - 3 } & Adequate and Flexible & SRC1 \\
\cline { 2 - 3 } & Supply Interruptions & SRC1 \\
\hline \multirow{4}{*}{ Environment } & Water Resources Conservation & ENC1 \\
\cline { 2 - 3 } & Limiting Pollution Sources & ENC2 \\
\cline { 2 - 3 } & Energy Consumption & ENC3 \\
\cline { 2 - 3 } & Water Quality & RRC1 \\
\cline { 2 - 3 } Social & Water Quantity & RRC2 \\
\hline \multirow{3}{*}{ Economic } & Health and Safety & ECC1 \\
\cline { 2 - 3 } & Cost/ Benefit & ECC2 \\
\cline { 2 - 3 } & Investment lost & ECC3 \\
\hline
\end{tabular}

\subsubsection{Grey Relational Analysis}

The main procedure of GRA processes are applied in parallel on the three main components of WSS: WS, WTP and WD. Tables $5 \mathrm{a}, \mathrm{b}$ and c clarify the normalized decision matrix and reference series, while tables $6 a, b$ and $c$ show difference matrices of WS, WTP and WD respectively. Then, grey relational coefficients are calculated as illustrated in tables $7 \mathrm{a}, \mathrm{b}$ and c. Later, by considering the weighted criteria, grey relational grades of all WS, WTP and WD alternatives are computed as shown in tables $8 \mathrm{a}, \mathrm{b}$ and $\mathrm{c}$.

Table 5a WS Normalized Decision Matrix and Reference Series

\begin{tabular}{|c|c|c|c|c|c|c|c|c|c|c|c|c|}
\hline $\begin{array}{c}\text { Strategy/ } \\
\text { Sub- } \\
\text { Criteria }\end{array}$ & $\mathrm{SRC1}$ & SRC2 & $\mathrm{SRC}_{3}$ & ENC1 & ENC1 & $\mathrm{ENC1}$ & RRCI & RRCI & RRCI & $\mathrm{ECCl}$ & $\mathrm{ECCl}$ & $\mathrm{ECCl}$ \\
\hline SA1 & 1 & 0 & 0 & 1 & 0 & 0 & 0 & 0 & 1 & 0.500 & 0.500 & 0 \\
\hline SA2 & 0 & 1 & 1 & 0 & 1 & 0.500 & 0 & 0.5 & 0 & 1 & 0 & 0 \\
\hline SA3 & 1 & 1 & 0 & 1 & 0.500 & 1 & 0 & 1 & 0.6667 & 0 & 0500 & 1 \\
\hline SA4 & 0 & 0 & 0 & 0 & 0 & 0.500 & 0 & 0.500 & 0.6667 & 1 & 0 & 0 \\
\hline SA5 & 1 & 0 & 1 & 0 & 0 & 1 & 1 & 0.500 & 1 & 1 & 1 & 1 \\
\hline
\end{tabular}

Table 5b WTP Normalized Decision Matrix and Reference Series

\begin{tabular}{|c|c|c|c|c|c|c|c|c|c|c|c|c|}
\hline $\begin{array}{l}\text { Strategy/ } \\
\text { Sub-Criteria }\end{array}$ & SRCI & $\mathrm{SRC} 2$ & $\mathrm{SRC} 3$ & ENCl & ENCI & ENCI & RRCI & RRC1 & RRC1 & ECCI & $\mathrm{ECCl}$ & ECCI \\
\hline TAI & 1 & 0 & 0 & 1 & 0 & 0 & 1 & 0 & 1 & 0.500 & 1 & 0 \\
\hline TA2 & 0 & 1 & 1 & 0 & 1 & 0.500 & 0 & 0.500 & 0 & 1 & 0 & 0 \\
\hline $\mathrm{TA}_{3}$ & 1 & 1 & 0 & 1 & 0.500 & 1 & 0 & 1 & 0.667 & 0 & 1 & 1 \\
\hline TA4 & 0 & 0 & 0 & 0 & 0 & 0.500 & 0 & 0.50 & 0.067 & 1 & 0 & 0 \\
\hline
\end{tabular}


A Decision Support System for Risk Management with Application to Water Supply Systems in Egypt

Table 5c WD Normalized Decision Matrix and Reference Series

\begin{tabular}{|c|c|c|c|c|c|c|c|c|c|c|c|c|}
\hline $\begin{array}{c}\text { Strategy' } \\
\text { Sub- } \\
\text { Criteria }\end{array}$ & SRCl & $\mathrm{SRC2}$ & $\mathrm{SRC} 3$ & ENCI & ENC1 & $\mathrm{ENCl}$ & $\mathrm{RRCl}$ & RRCI & $\mathrm{RRCl}$ & $\mathrm{ECCl}$ & $\mathrm{ECCl}$ & $\mathrm{ECCl}$ \\
\hline DA1 & 1 & 1 & 0.500 & 1 & 0.500 & 1 & 0 & 0 & 1 & 1 & 1 & 0.500 \\
\hline DA2 & 0.500 & 1 & 1 & 0.500 & 1 & 0500 & 0 & 0500 & 0 & 1 & 0.500 & 0.500 \\
\hline DA3 & 0 & 0 & 0.500 & 0 & 0.500 & 1 & 0 & 1 & 0 & 0 & 0 & 1 \\
\hline DA4 & 1 & 1 & 0.500 & 1 & 0 & 0.500 & 0500 & 1 & 1 & 1 & 0.500 & 0.500 \\
\hline DA5 & 0 & 0.500 & 0 & 0.500 & 0 & 0 & 1 & 0.500 & 0 & 1 & 0 & 0 \\
\hline
\end{tabular}

Table 6a WS Difference Matrix

\begin{tabular}{|c|c|c|c|c|c|c|c|c|c|c|c|c|}
\hline $\begin{array}{c}\text { Strategy' } \\
\text { Sub- } \\
\text { Criteria }\end{array}$ & $\mathrm{SRCl}$ & $\mathrm{SRC} 2$ & $\mathrm{SRC} 3$ & ENCI & ENCI & ENCI & RRCl & RRCI & RRCl & $\mathrm{ECCl}$ & $\mathrm{ECCl}$ & $\mathrm{ECCl}$ \\
\hline SA1 & 0 & 1 & 1 & 0 & 1 & 1 & 1 & 1 & 0 & 0.500 & 0.5 & 11 \\
\hline SA2 & 1 & 0 & 0 & 1 & 0 & 0.5 & 1 & 0.5 & 1 & 0 & 1 & 1 \\
\hline $\mathrm{SA} 3$ & 0 & 0 & 1 & 0 & 0.5 & 0 & 1 & 0 & 0.3333 & 1 & 0.5 & 0 \\
\hline SA4 & 1 & 1 & 1 & 1 & 1 & 0.5 & 1 & 0.5 & 0.3333 & 0 & 1 & 1 \\
\hline SA5 & 0 & 1 & 0 & 1 & 1 & 0 & 0 & 0.5 & 0 & 0 & 0 & 0 \\
\hline
\end{tabular}

Table 6b WTP Difference Matrix

\begin{tabular}{|c|c|c|c|c|c|c|c|c|c|c|c|c|}
\hline $\begin{array}{c}\text { Strategy/ } \\
\text { Sub- } \\
\text { Criteria }\end{array}$ & SRCl & $\mathrm{SRC} 2$ & $\mathrm{SRC} 3$ & ENCI & ENCI & ENCI & $\mathrm{RRCl}$ & $\mathrm{RRCl}$ & RRCI & $\mathrm{ECCl}$ & $\mathrm{ECCl}$ & $\mathrm{ECCl}$ \\
\hline TA1 & 0 & 1 & 1 & 0 & 1 & 1 & 0 & 1 & 0 & 0.500 & 0 & 1 \\
\hline TA2 & 1 & 0 & 0 & 1 & 0 & 0.500 & 1 & 0.500 & 1 & 0 & 1 & 1 \\
\hline TA 3 & 0 & 0 & 1 & 0 & 0.500 & 0 & 1 & 0 & 0.333 & 1 & 0 & 0 \\
\hline TA4 & 1 & 1 & 1 & 1 & 1 & 0.500 & 1 & 0.500 & 0.333 & 0 & 1 & 1 \\
\hline
\end{tabular}

Table 6c WD Difference Matrix

\begin{tabular}{|c|c|c|c|c|c|c|c|c|c|c|c|c|}
\hline $\begin{array}{c}\text { Strategy/ } \\
\text { Sub- } \\
\text { Criteria }\end{array}$ & SRC1 & $\mathrm{SRC2}$ & $\mathrm{SRC}_{3}$ & ENCI & ENCI & ENCI & RRCI & RRCI & RRCI & $\mathrm{ECCl}$ & $\mathrm{ECCl}$ & ECC1 \\
\hline DA1 & 0 & 0 & 0.500 & 0 & 0.500 & 0 & 1 & 1 & 0 & 0 & 0 & 0.500 \\
\hline DA2 & 0.500 & 0 & 0 & 0.500 & 0 & 0.500 & 1 & 0.500 & 1 & 0 & 0.500 & 0.500 \\
\hline DA3 & 1 & 1 & 0.500 & 1 & 0.500 & 0 & 1 & 0 & 1 & 1 & 1 & 0 \\
\hline DA4 & 0 & 0 & 0.500 & 0 & 1 & 0.500 & 0.500 & 0 & 0 & 0 & 0.500 & 0.500 \\
\hline DA5 & 1 & 0.500 & 1 & 0.500 & 1 & 1 & 0 & 0.500 & 1 & 0 & 1 & 1 \\
\hline
\end{tabular}

Table 7a WS Grey Relational Coefficients

\begin{tabular}{|c|c|c|c|c|c|c|c|c|c|c|c|c|}
\hline $\begin{array}{c}\text { Strategy/ } \\
\text { Sub- } \\
\text { Criteria }\end{array}$ & $\mathrm{SRCl}$ & $\mathrm{SRC}_{2}$ & SRC3 & $\mathrm{ENCl}$ & $\mathrm{ENCl}$ & $\mathrm{ENCl}$ & RRCI & $\mathrm{RRCl}$ & $\mathrm{RRCl}$ & $\mathrm{ECCl}$ & $\mathrm{ECCl}$ & $\mathrm{ECCl}$ \\
\hline SA1 & 1 & 0.333 & 0.333 & 1 & 0.3333 & 0.333 & 0.333 & 0.333 & 1 & 0.500 & 0.500 & 0.333 \\
\hline SA2 & 0.333 & 1 & 1 & 0.333 & 1 & 0.500 & 0.333 & 0.500 & 0.333 & 1 & 0.333 & 0.333 \\
\hline SA3 & 1 & 1 & 0.333 & 1 & 0.500 & 1 & 0.333 & 1 & 0.600 & 0.333 & 0.500 & 1 \\
\hline SA4 & 0.333 & 0.333 & 0.333 & 0.333 & 0.333 & 0.500 & 0.333 & 0.500 & 0.600 & 1 & 0.333 & 0.333 \\
\hline SA5 & 1 & 0.333 & 1 & 0.333 & 0.333 & 1 & 1 & 0.500 & 1 & 1 & 1 & 1 \\
\hline
\end{tabular}

Table 7b WTP Grey Relational Coefficients

\begin{tabular}{|c|c|c|c|c|c|c|c|c|c|c|c|c|}
\hline $\begin{array}{c}\text { Strategy/ } \\
\text { Sub-Criteria }\end{array}$ & $\mathrm{SRC1}$ & $\mathrm{SRC}_{2}$ & SRC3 & $\mathrm{ENCl}$ & $\mathrm{ENCl}$ & $\mathrm{ENCl}$ & RRCI & $\mathrm{RRCl}$ & $\mathrm{RRCl}$ & $\mathrm{ECCl}$ & $\mathrm{ECCl}$ & $\mathrm{ECCl}$ \\
\hline TA1 & 1 & 0.333 & 1 & 0.333 & 0.333 & 0.333 & 1 & 0.333 & 1 & 0.500 & 1 & 0.333 \\
\hline TA2 & 0.333 & 1 & 0.333 & 1 & 1 & 0.500 & 0.333 & 0.500 & 0.333 & 1 & 0.333 & 0.333 \\
\hline TA3 & 1 & 0.333 & 1 & 0.500 & 0.500 & 1 & 0.333 & 1 & 0.600 & 0.333 & 1 & 1 \\
\hline TA4 & 0.333 & 0.333 & 0.333 & 0.333 & 0.333 & 0.500 & 0.333 & 0.500 & 0.600 & 1 & 0.333 & 0.333 \\
\hline
\end{tabular}


Table 7c WD Grey Relational Coefficients

\begin{tabular}{|c|c|c|c|c|c|c|c|c|c|c|c|c|}
\hline $\begin{array}{c}\text { Strategyl } \\
\text { Sub- } \\
\text { Criteria }\end{array}$ & SRCI & $\mathrm{SRC2}$ & $\mathrm{SRC} 3$ & $\mathrm{ENCl}$ & ENCl & ENCl & $\mathrm{RRCl}$ & $\mathrm{RRCl}$ & RRCI & $\mathrm{ECCl}$ & $\mathrm{ECCl}$ & $\mathrm{ECCl}$ \\
\hline DA1 & 1 & 1 & 0.500 & 1 & 0.500 & 1 & 0.333 & 0.333 & 1 & 1 & 1 & 0.500 \\
\hline DA2 & 0.500 & 1 & 1 & 0.500 & 1 & 0.500 & 0.333 & 0.500 & 0.333 & 1 & 0.500 & 0.500 \\
\hline DA3 & 0.333 & 0.333 & 0.500 & 0.333 & 0.500 & 1 & 0.333 & 1 & 0.333 & 0.333 & 0.333 & 1 \\
\hline DA4 & 1 & 1 & 0.500 & 1 & 0.333 & 0.500 & 0.500 & 1 & 1 & 1 & 0.500 & 0.500 \\
\hline DA5 & 0.333 & 0.500 & 0.333 & 0.500 & 0.333 & 0.333 & 1 & 0.500 & 0.333 & 1 & 0.3333 & 0.333 \\
\hline
\end{tabular}

Table 8a WS Grey Relational Grades

\begin{tabular}{|c|c|c|c|c|c|c|c|c|c|c|c|c|c|}
\hline $\begin{array}{l}\text { Strategyl } \\
\text { Sub- } \\
\text { Criteria }\end{array}$ & SRCI & SRC2 & SRC3 & ENC1 & ENC1 & ENC1 & RRCI & RRCl & $\mathrm{RRC1}$ & ECCl & ECCl & $\mathrm{ECCl}$ & Grade \\
\hline SA1 & 0.100 & 0.033 & 0.0233 & 0.0800 & 0.0300 & 0.0267 & 0.0267 & 0.0300 & 0.0800 & 0.035 & 0.035 & 0.0300 & 0.5300 \\
\hline SA2 & 0.033 & 0.100 & 0.0700 & 0.0267 & 0.0900 & 0.0400 & 0.0267 & 0.045 & 0.0267 & 0.0700 & 0.0233 & 0.0300 & 0.5817 \\
\hline SA3 & 0.100 & 0.100 & 0.0233 & 0.0800 & 0.0450 & 0.0800 & 0.0267 & 0.0900 & 0.048 & 0.0233 & 0.035 & 0.0900 & 0.7413 \\
\hline SA4 & 0.033 & 0.033 & 0.0233 & 0.0267 & 0.0300 & 0.0400 & 0.0267 & 0.0450 & 0.048 & 0.0700 & 0.0233 & 0.0300 & 0.4297 \\
\hline SA5 & 0.100 & 0.033 & 0.0700 & 0.0267 & 0.0300 & 0.0800 & 0.0800 & 0.0450 & 0.0800 & 0.0700 & 0.0700 & 0.0900 & 0.7750 \\
\hline
\end{tabular}

Table 8b WTP Grey Relational Grades

\begin{tabular}{|c|c|c|c|c|c|c|c|c|c|c|c|c|c|}
\hline $\begin{array}{l}\text { Strategyl } \\
\text { Sub- } \\
\text { Criteria }\end{array}$ & SRCI & SRC2 & SRC3 & ENC1 & ENC1 & ENCl & RRC1 & RRC1 & RRC1 & ECCI & ECCI & ECC1 & Grade \\
\hline TA1 & 0.030 & 0.033 & 0.023 & 0.080 & 0.030 & 0.026 & 0.080 & 0.030 & 0.080 & 0.035 & 0.070 & 0.030 & 0.5483 \\
\hline TA2 & 0.030 & 0.100 & 0.070 & 0.026 & 0.090 & 0.040 & 0.026 & 0.045 & 0.026 & 0.070 & 0.023 & 0.030 & 0.5817 \\
\hline TA3 & 0.100 & 0.100 & 0.023 & 0.080 & 0.045 & 0.080 & 0.026 & .0900 & 0.048 & 0.023 & 0.070 & 0.090 & 0.7763 \\
\hline TAA & 0.033 & 0.033 & 0.023 & 0.026 & 0.030 & 0.040 & 0.026 & 0.045 & 0.048 & 0.070 & 0.023 & 0.030 & 0.4296 \\
\hline
\end{tabular}

Table 8c WD Grey Relational Grades

\begin{tabular}{|c|c|c|c|c|c|c|c|c|c|c|c|c|c|}
\hline $\begin{array}{l}\text { Strategyl } \\
\text { Sub- } \\
\text { Criteria }\end{array}$ & SRC1 & $\mathrm{SRC}_{2}$ & SRC3 & ENCl & ENCI & ENCI & RRC1 & $\mathrm{RRCl}$ & RRCl & $\mathrm{ECCl}$ & $\mathrm{ECCl}$ & ECC1 & Grade \\
\hline DA1 & 0,100 & 0.100 & 0.035 & 0.080 & 0.045 & 0,080 & 0.026 & 0.030 & 0.080 & 0.070 & 0,070 & 0.045 & 0.7617 \\
\hline DA2 & 0.050 & 0.100 & 0.070 & 0.040 & 0.090 & 0.040 & 0.026 & 0.045 & 0.023 & 0.070 & 0.035 & 0.045 & 0.6383 \\
\hline DA3 & 0.033 & 0.033 & 0.035 & 0.026 & 0.045 & 0.080 & 0.026 & 0.090 & 0.023 & 0.023 & 0.023 & 0.0900 & 0.5333 \\
\hline DA4 & 0.100 & 0.100 & 0.035 & 0.080 & 0.030 & 0.040 & 0.040 & 0.090 & 0.080 & 0.070 & 0.035 & 0.045 & 0.7450 \\
\hline DA5 & 0.033 & 0.050 & 0.023 & 0.040 & 0.030 & 0.026 & 0.080 & 0.045 & 0.026 & 0.070 & 0.023 & 0.030 & 0.4783 \\
\hline
\end{tabular}

It can be noted from GRA results for strategies evaluation that: -

- For WS risks response alternatives, the fifth (SA5) strategy has the highest evaluation. This can be explained because it involves proposing new alternative water sources, such as groundwater sources used in parallel with existing surface water sources, which can maximize water resource utilization and achieve high responsiveness and influence in mitigating the impact of water source risks on overall water supply systems. In addition, the third strategy (SA3) has the second highest evaluation because it proposes water treatment of sludge instead of draining the sludge into the water source. This has the advantage of obtaining economic benefits from dry sludge and also prevents deterioration of water quality caused by sludge disposal.

- Dealing with the risks of WTPs, the third strategy (TA3) that proposes a dosage plan to ensure reasonable disinfection and coagulation dosage has the highest grade. Therefore, because it does not meet the treated water quality standards, it has a great impact on reducing risks.

- Wherever, from WD risks perspective, the first strategy (DA1) that focused on reducing leakage reduction (DA1) by repairing pipe leaks and rehabilitation of the network has the evaluation advantage due to its effect in improvement the discharged water quantity , target pressure and non-revenue water reduction. 

Egypt

- Strategies with low overall rankings and relatively limited time can be regarded as temporary strategies and can be implemented simultaneously with other high-priority and permanent strategies.

\subsection{Residual Risks Monitoring}

In this research, a residual risk monitoring is proposed to evaluate the risk reduction performance of various risk response programs. However, Table 9 lists all the calculated risk reductions for the existing risk levels, as well as the expected risk scores and categories to be achieved after implementing the alternatives.

Table 9 Residual Risks Monitoring

\begin{tabular}{|c|c|c|c|c|c|c|c|c|c|c|c|c|c|c|c|c|c|c|c|c|c|c|c|c|}
\hline$\frac{\pi}{\frac{\pi}{20}}$ & 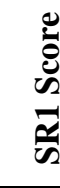 & & 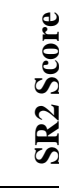 & & 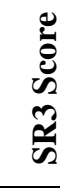 & & 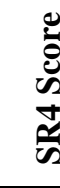 & & שֶ. & & $\frac{\mathscr{b}}{\mathscr{b}}$ & & 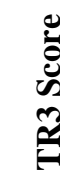 & & 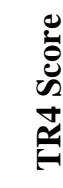 & & & & 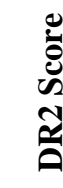 & & 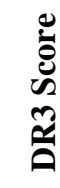 & & $\begin{array}{l}\tilde{\omega} \\
\dot{\alpha} \\
\tilde{a}\end{array}$ & \\
\hline $\overrightarrow{\bar{E}}$ & $\begin{array}{l}0 \\
0 \\
0 \\
0 \\
0\end{array}$ & $\underset{⿱ 亠 凶}{\gtrless}$ & $\begin{array}{l}0 \\
0 \\
0 \\
0\end{array}$ & $\stackrel{\bar{g}}{\stackrel{4}{4}}$ & $\begin{array}{l}0 \\
0 \\
0 \\
0 \\
0\end{array}$ & 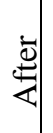 & $\begin{array}{l}\frac{0}{0} \\
\frac{0}{0} \\
\infty\end{array}$ & $\stackrel{\frac{\pi}{4}}{4}$ & $\begin{array}{l}0 \\
0 \\
0 \\
0\end{array}$ & 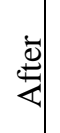 & $\begin{array}{l}0 \\
0 \\
0 \\
0\end{array}$ & $\stackrel{\bar{E}}{\mathbb{E}}$ & $\begin{array}{l}0 \\
0 \\
0 \\
0\end{array}$ & 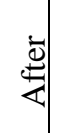 & $\begin{array}{l}0 \\
0 \\
0 \\
0 \\
0\end{array}$ & 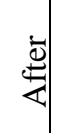 & $\begin{array}{l}0 \\
0 \\
0 \\
0 \\
0\end{array}$ & $\stackrel{\square}{\square}$ & $\begin{array}{l}0 \\
0 \\
0 \\
0\end{array}$ & 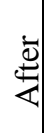 & $\begin{array}{l}\stackrel{0}{0} \\
\stackrel{0}{0} \\
\infty\end{array}$ & $\underbrace{\frac{0}{2}}_{\vec{c}}$ & $\begin{array}{c}\frac{0}{0} \\
\stackrel{0}{0} \\
\infty\end{array}$ & $\frac{\overrightarrow{0}}{2}$ \\
\hline $\begin{array}{c}\mathrm{A} \\
1 \\
\end{array}$ & & $\stackrel{m}{0}$ & 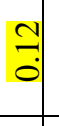 & $\stackrel{8}{:}$ & & 8 & 으. & ?ै. & & & & & & & & & & $\stackrel{m}{0}$ & & & & $\begin{array}{c}2 \\
0 \\
0\end{array}$ & $\stackrel{0}{0}$ & 0 \\
\hline $\begin{array}{l}\text { A } \\
2\end{array}$ & & $\stackrel{?}{0}$ & $\frac{7}{0}$ & $\stackrel{n}{\text { ? }}$ & & $\stackrel{\infty}{\circ}$ & 으. & 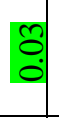 & & & & & & & & & & $\stackrel{\simeq}{0}$ & & & & $\begin{array}{l}\infty \\
\stackrel{0}{0}\end{array}$ & 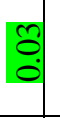 & $\ddot{0}$ \\
\hline $\begin{array}{l}\text { A } \\
3\end{array}$ & & $\stackrel{0}{0}$ & $\stackrel{0}{0}$ & ڤ̊ & & है & 응. & 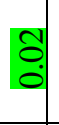 & & & & & & 0 & & $\stackrel{8}{0}$ & & ộ. & & 2 & & $\stackrel{0}{\circ}$ & ? & อ. \\
\hline $\begin{array}{l}\mathrm{A} \\
4 \\
\end{array}$ & & & $\stackrel{7}{0}$ & $\stackrel{0}{0}$ & & $\stackrel{7}{0}$ & $\stackrel{5}{0}$ & $\stackrel{+}{0}$ & & & & & & & & & & & & & & $=$ & ฮี & 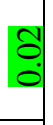 \\
\hline $\begin{array}{l}\text { S } \\
\text { A } \\
5\end{array}$ & & $\stackrel{?}{\circ}$ & $\frac{1}{0}$ & @̊. & & $\stackrel{ \pm}{0}$ & $\stackrel{5}{0}$ & 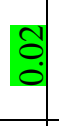 & & & & $\begin{array}{l}\stackrel{0}{\circ} \\
\stackrel{0}{0}\end{array}$ & & $\begin{array}{l}\infty \\
0 \\
0 \\
0\end{array}$ & & $\stackrel{\infty}{\stackrel{0}{0}}$ & & : & & $\begin{array}{l}\infty \\
0 \\
0 \\
0\end{array}$ & & ○. & $\stackrel{3}{0}$ & $\stackrel{0}{\circ}$ \\
\hline 1 & & $\stackrel{m}{\circ}$ & $\stackrel{7}{0}$ & ?̊. & & $\stackrel{8}{0}$ & 으. & है. & & & & & & & & & & $\stackrel{m}{0}$ & & & & $\stackrel{\infty}{0}$ & סִ & $\stackrel{0}{0}$ \\
\hline $\mathrm{T}$ & & & $\stackrel{1}{0}$ & $\begin{array}{l}\text { ?े } \\
\text { co }\end{array}$ & & $\stackrel{8}{0}$ & 훙. & $\stackrel{3}{0}$ & & & & & & & & & & $\stackrel{1}{0}$ & & & & $\stackrel{\infty}{\stackrel{\infty}{0}}$ & $\stackrel{\text { On}}{0}$ & $\stackrel{0}{0}$ \\
\hline $\begin{array}{l}\mathrm{T} \\
\mathrm{A} \\
3 \\
\end{array}$ & & $\stackrel{?}{\circ}$ & 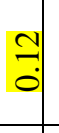 & $\begin{array}{l}\tilde{\sigma} \\
0 \\
0\end{array}$ & & $\stackrel{0}{0}$ & ำ. & $\begin{array}{l}\tilde{b} \\
0\end{array}$ & & & & $\begin{array}{l}0 \\
\stackrel{2}{0} \\
0\end{array}$ & & 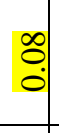 & & $\stackrel{\infty}{\stackrel{0}{0}}$ & & : & & $\begin{array}{l}\infty \\
0 \\
0\end{array}$ & & $\stackrel{d}{0}$ & $\begin{array}{l}\tilde{O} \\
\dot{0}\end{array}$ & o. \\
\hline $\begin{array}{l}\mathrm{T} \\
\mathrm{A} \\
4 \\
\end{array}$ & & & $\because$ & ¿̣̂. & & $\overline{0}$ & 오. & $\stackrel{+}{0}$ & & & & & & & & & & \pm & & & & $\stackrel{0}{\circ}$ & ?ִ. & రి \\
\hline $\begin{array}{l}\text { D } \\
\text { A } \\
1 \\
\end{array}$ & & $\stackrel{0}{0}$ & $\stackrel{0}{0}$ & $\stackrel{3}{0}$ & & $\stackrel{n}{0}$ & 훙. & $\stackrel{1}{0}$ & & $\stackrel{0}{\circ}$ & & oे. & & $\begin{array}{l}0 \\
0 \\
0\end{array}$ & & oे. & & 잉. & & : & & & ?ִ & o. \\
\hline D & & $\frac{0}{0}$ & $\stackrel{1}{0}$ & $\stackrel{\Xi}{0}$ & & 오. & ؛ै. & ?ీ. & & $\stackrel{ \pm}{ \pm}$ & & $\stackrel{m}{0}$ & & $\frac{m}{0}$ & $\check{m}$ & $\stackrel{m}{\overrightarrow{0}}$ & & 읭 & & $\stackrel{m}{0}$ & & ๑̊ & ?. & 무. \\
\hline
\end{tabular}




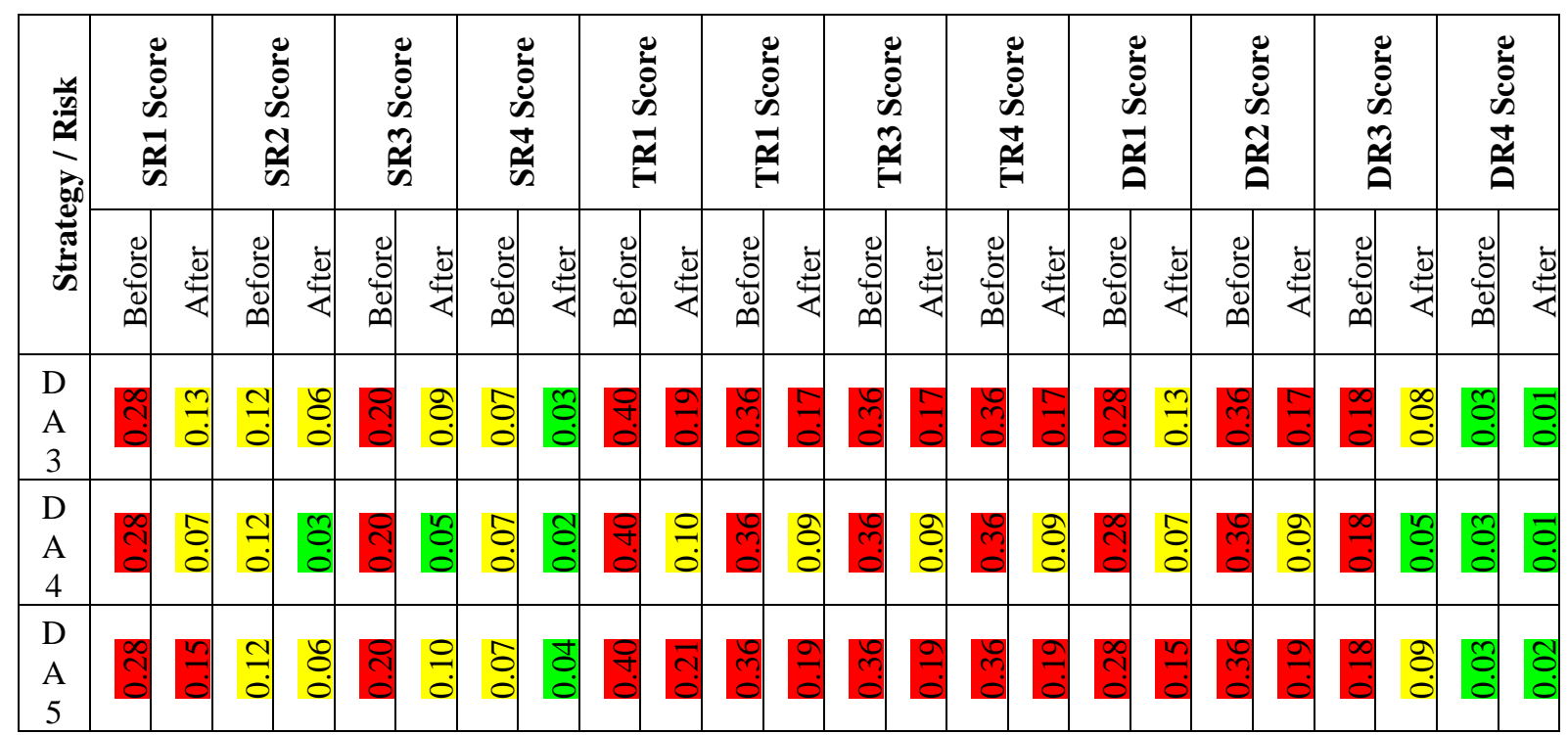

Table 9 shows a noted risk reductions for various risk scores as well as the risk categories after implementation the proposed response alternatives. The red, yellow and green colors indicate HR, MR and LR categories respectively.

\section{CONCLUSIONS}

- In this article, the risk management methodology was used in order to identify, evaluate and treat the most critical risk events for Cairo water supply systems. The critical risk events for water source, treatment plants and distribution networks were identified.

- For risk analysis, the GRM approach was done with the purpose to estimate risks probability and impact as well as risk categories.

- In order to mitigate the impact of various critical risks, many response alternatives are developed. However GRA method is applied for evaluating these alternatives. It helps to compare possible action options for various main components of study area water supply system.

- According to ALARP principle for monitoring the residual risks, an effective risk reduction is noted after implementation of various risk response alternatives.

\section{REFERENCES}

[1] Bitton, G., (1994). Indicator microorganisms, pp. 101. In: Wastewater Microbiology. WileyLiss, Inc.,U. S. A.

[2] Bosch, C., K. Hommann, C. Sadoff and L. Travers, 2000. Water Sanitation and Poverty. PRSP Source Book, World Bank.

[3] Cairo water company (CWC) technical report, 2014.

[4] El-Sadek, A., (2007). Upscaling field scale hydrology and water quality modeling to catchment scale.Water Res. Managem. 21:149-169.

[5] Garcia-Armisen, T., A. Goncalves, G. Billen, and P. Servais, (2007). Modeling microbiological water quality in the Seine River drainage network: Past, present and future situations. Hydrol. Earth.Syst. Sci. 11: 1581-1592.

[6] Karaboze, I., F. Ucar, R. Eltem, G. Ozdmir, and M. Ates, (2003). Determination of existence and count of pathogenic microorganisms in Izmir Bay. JES 26:1-18.

[7] LeChevallier, MW, (2003). The potential for health risks from intrusion of contaminants into the distribution system from pressure transients. Journal of Water and Health, 1(1): 3-14. 
A Decision Support System for Risk Management with Application to Water Supply Systems in Egypt

[8] McInnis A. (2001), The New Engineering Contract: A legal commentary; Thomas Telford Publishing; London.

[9] Özçelik, F., \& Öztürk Avcı, B. (2014). Evaluation of banks' sustainability performance in Turkey with grey relational analysis. The Journal of Accounting and Finance, 63, 189-209.

[10] Project Management Institute, Inc. (2013). A Guide to the Project Management Body of Knowledge (PMBOK ${ }^{\circledR}$ Guide), Fifth Edition. Newtown Square, Pennsylvania: Project Management Institute, Inc.

[11] Rifaat, H.M., (2007). Bacterial quality of River Nile water at Cairo region in Egypt. Suoseura Finnish Peatland Soc. Helsinki, Suo 59 (1-2): 1-8.

[12] Reynolds, K.A., K.D. Mena and C.P. Gerba, (2008). Risk of waterborne illness via drinkable water in the United States. In: Reviews of Environmental Contamination and Toxicology (pp. 117-158), Springer.

[13] Rosén, L., Hokstad, P., Lindhe, A., Sklet, S., Røstum, J. (2007): Generic Framework and Methods for Integrated Risk Management in Water Safety Plans, TECHNEAU, 2007.

[14] TECHNEAU (2005). Technology enabled universal access to safe water (TECHNEAU). Annex I: Description of work. Proposal/Contract no.: 018320-02. EU Sixth Framework programme. 